\title{
Management along a gradient: Southeast Sulawesi's cacao production landscapes
}





\section{Management along a gradient: Southeast Sulawesi's cacao production landscapes}

Lisa C. Kelley

Working Paper 176 


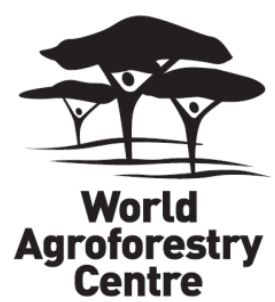

\section{Correct citation:}

Kelley LC. 2013. Management along a gradient: Southeast Sulawesi's cacao production landscapes. Working Paper 176. Bogor, Indonesia: World Agroforestry Centre (ICRAF) Southeast Asia Regional Program. DOI: 10.5716/WP13265.PDF.

Titles in the Working Paper Series share interim results on agroforestry research and practices to stimulate feedback from the scientific community. Other publication series from the World Agroforestry Centre include agroforestry perspectives, technical manuals and occasional papers.

Published by the World Agroforestry Centre

Southeast Asia Regional Program

PO Box 161, Bogor 16001

Jawa Barat

Indonesia

Tel: +62 2518625415

Fax: +62 2518625416

Email: icraf-indonesia@cgiar.org

Website: http://worldagroforestry.org/regions/southeast_asia

(c) World Agroforestry Centre 2013

Working Paper 176

\section{Photos:}

The views expressed in this publication are those of the author(s) and not necessarily those of the World Agroforestry Centre.

Articles appearing in this publication may be quoted or reproduced without charge, provided the source is acknowledged.

All images remain the sole property of their source and may not be used for any purpose without written permission of the source. 


\section{About the author}

Lisa C. Kelley is a PhD student at the University of California, Berkeley, in the Department of Environmental Science, Policy and Management. Her work focuses on conservation strategies and land-use transitions in Southeast Asia's agricultural landscapes. Prior to study at Berkeley, Lisa worked for The Nature Conservancy, The Wildlife Trade Monitoring Network (TRAFFIC) and The Center for People and Forests (RECOFTC). Her work with these organizations addressed questions related to forest governance and land use, with a particular focus on community forest management and REDD+ in Southeast Asia. Lisa received her BA in Ecology and Evolutionary Biology from Princeton University in 2008. 


\begin{abstract}
Indonesia's cacao production landscapes are increasingly important sites for supporting social and ecological sustainability. To inform these efforts, this study presents information on the history of cacao cultivation, current management practices, factors influencing these practices, and ongoing developments related to land in Southeast Sulawesi. Three findings are highlighted. First, despite the commonality of a full-sun growing strategy, a diversity of management practices persists, some of which challenge common renderings of socio-ecological trade-offs. Second, current levels of production loss suggest the potential transience of cacao as a livelihood strategy and source of wildlife habitat in Indonesia, highlighting the need to study socio-ecological trade-offs over a long time period and in relation to other cropping systems. Third, while many efforts to boost social or ecological sustainability assume that farmers make decisions on the basis of economic risk and return, management practices appear to be more often informed by the quality and orientation of institutional support farmers receive.
\end{abstract}

Keywords: cacao, cocoa, management practices, land-use dynamics, livelihoods, Southeast Sulawesi 


\section{Acknowledgements}

This study was funded by the Department of Foreign Affairs, Trade and Development, Canada, through the Agroforestry and Forestry: Linking Knowledge to Action project and by the University of California, Berkeley's Diversified Farming Systems Group. The author appreciates the contributions of collaborating villagers and officials as well as research support from Safaruddin, Jusupta Tarigan, Anang Setiawan, Elisabeth Fransina, Troy Pamungkas, Jhon Roy Sirait, Horas Napitupulu, and Yulius Bari. The author would also like to thank Matthew D. Potts and James M. Roshetko for assistance in editing the manuscript. 



\section{Contents}

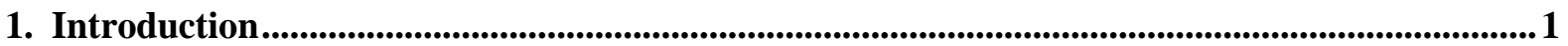

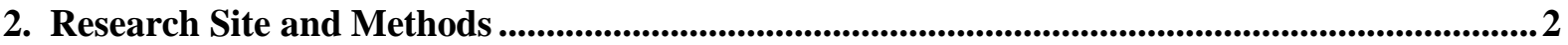

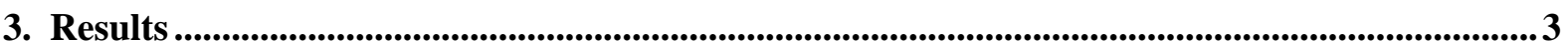

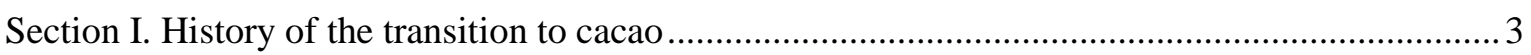

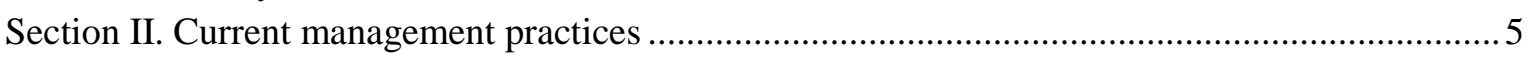

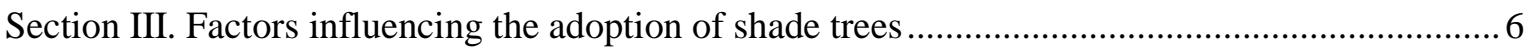

Section IV. Cacao in relation to continuing land developments ..................................................... 9

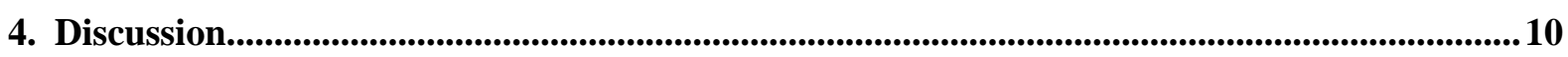

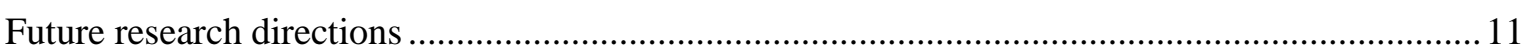

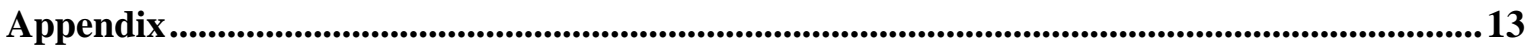

References ......................................................................................................................................................... 15

\section{List of Figure}

Figure 1. Changes by land-cover classification (mainland Southeast Sulawesi 1990-2001) ............... 4

Figure 2. Production classifications in the study villages ....................................................................5

Figure 3. Typical farm in Asipako with cacao monoculture showing evidence of eliminated gamal shade trees 



\section{Introduction}

Indonesia is the latest centre of the cacao boom and potential cacao bust. Since the late 1980s, more hectares of land have been converted to cacao production than anywhere else in the world (Clough et al 2009). Indonesia has become the third-largest producer of cocoa beans globally, producing a $15 \%$ share of the world supply, with exports amounting to over USD 0.9 billion annually (FAOSTAT 2013, WCF 2007, World Bank 2009). Despite this growth, widespread production losses have been observed in Indonesia since the early 2000s, reflected in oscillating export figures (AgroAsia 2012, Listiyorini 2012, Direktorat Jenderal Perkebunan 2012). Cacao farmers have experienced pest outbreaks, particularly the Cacao Pod Borer (Bos et al 2007, Klein et al 2002); irregular but pronounced droughts associated with the El Niño Southern Oscillation (for example, Schwendenmann et al 2010); and the spread of fungal pathogens, particularly Black Pod Rot and Vascular Streak Dieback (for example, Neilson 2007, Listiyorini 2011, Pardomuan 2011).

Much work analyzing cacao production landscapes in Indonesia has examined the socio-ecological trade-offs associated with different production practices. Cacao (Theobroma cacao L.) is an understorey tree species native to the Amazon that can be grown in complex multi-storey farms. Despite this, most cacao in Indonesia is cultivated under a full-sun monocultural strategy (Belsky and Siebert 2003). Attempts to explain why farmers choose a full-sun strategy generally emphasize the higher yields (and higher incomes) it is possible to obtain from a full-sun approach (for example, Tscharntke et al 2011, Steffan-Dewenter et al 2007). In contrast, analysts tend to suggest that farmers adopting a more diverse multi-storey cropping strategy accept potentially lower returns but do so because risk is also lower. Shade trees planted alongside cacao have been found to (i) provide resources that support the natural enemies of pests; (ii) protect cacao trees from physiological stress; and (iii) prevent the growth of a competitive weed bank that might harbour pests and diseases (for example, Bos et al 2007). This confers a degree of environmental resilience-sustaining yields and other ecosystem services more dependably than monocultural strategies in the face of environmental variability (Holt-Gimenez et al 2002, Lin et al 2008, Vandermeer et al 1998, Schwendenmann et al 2010) — as well as economic resilience, providing an additional source of livelihoods for farmers who find their incomes reduced from cacao (Tscharntke et al 2011).

The nature of these trade-offs and the extent to which they characterize actual farmer decision-making processes has important implications for efforts to support social and ecological sustainability in cacao production landscapes. In particular, many emerging certification programs (for example, Rainforest Alliance) aim to create incentives for relatively more diverse multi-storey farms on the basis of an assumption that (i) such farms provide a critical source of habitat for many endangered wildlife species; and (ii) certification can provide a price premium per hectare that will offset the disadvantages to smallholders' incomes associated with shading practices (Steffan-Dewenter et al 2007). Understanding the validity of these assumptions, however, is limited by three gaps in current analyses of socio-ecological trade-offs. First, it is often assumed that there is a neat correspondence between maintaining shade trees and providing wildlife habitat, failing to examine the other management practices that may shape biodiversity outcomes. Second, the longevity of cacao habitat in a landscape is often not incorporated in a discussion of socio-ecological trade-offs. This is 
particularly important given the potential of cacao 'bust' suggested by the current production losses. Third, and most importantly, almost all work done assumes farmers make decisions on the basis of risk and return, but very little work examines other, relatively more non-economic factors, which also shape farmers' decisions.

To help build understanding and inform management debates, this study aimed to collect information on:

I. the history of cacao cultivation;

II. current cacao management practices;

III. factors influencing cacao management; and

IV. continuing developments related to land.

This paper presents data from interviews and participant observation conducted over two months in Sulawesi, Indonesia, in the context of the World Agroforestry Centre's Agroforestry and Forestry in Sulawesi: Linking Knowledge and Action (AgFor) project. After briefly describing the sites selected for study and the data collection method, I share my initial findings and conclude with thoughts on implications and directions for future work.

\section{Research Site and Methods}

The field component of this research was conducted over six weeks from May to June 2012, with one week spent in each of four villages and two weeks spent in Kendari, Southeast Sulawesi, learning from staff of the AgFor project. The intended outcome of the AgFor project is improved equitable and sustainable agroforestry and forestry-based livelihoods' systems for rural communities in Sulawesi. To achieve the outcome, the project focuses on improving awareness, access and skills related to natural resources and agriculture; developing equitable participatory governance mechanisms; and integrating management of sustainable landscapes and ecosystems. Cacao is a major income source for rural families in the project area (Roshetko et al 2013).

The province of Southeast Sulawesi was selected for study because the island of Sulawesi produces the majority of the cacao in Indonesia ( 70\%), with Southeast Sulawesi responsible for $16 \%$ of the total national production (Direktorat Jenderal Perkebunan 2012). Southeast Sulawesi is also the site of initial work on the ICRAF-led components of the AgFor project. Working alongside ICRAF project staff, four villages were selected from Konaweha district in Southeast Sulawesi for in-depth study on the basis of reported differences in cacao cultivation practices. Villages were selected to provide sufficient basis to examine local variation while enabling tentative hypotheses about the general directions of past and present changes.

Of the four villages, Lawonua and Wonua Hoa lie roughly at sea level in the mostly deforested lowlands while Ambondia'a and Asipakolie are situated on the Konaweha River in the mostly still forested uplands. Whereas Lawonua and Wonua Hoa are characterized by high numbers of Bugis migrants (56\% and 37\% respectively, according to village leaders), Ambondia'a and Asipako are characterized by nearly exclusively Tolaki populations. Bugis migrants' management practices in the 
former two villages shaped cacao farming more broadly compared to the latter two (discussed further below).

In each village, I spent 4-5 days conducting informal interviews with cacao farmers, village elders and village leaders. I also spent 2-3 days conducting participant observation. Over 100 cacao farmers, village elders and village leaders were interviewed, with interviews generally lasting 10 minutes when discussing farmer production strategies and management challenges but up to two hours when discussing the history of village governance and land use. Interviews followed a semi-structured format developed through initial focus-group discussions with farmer groups in the region, conversations with AgFor project staff, and a literature review. When interviewing farmers, farms were also visited to better contextualize their perspectives of production strategies. Participant observation included harvesting and field preparation activities with farmers and participation in community events.

Given time limitations, an opportunistic sampling approach was adopted. Farmers and other villagers were approached when in their fields or near their houses. Sampling was stratified to the extent possible, however, with roughly equal time devoted to conducting interviews in each of a village's neighbourhoods. I adopted a purposive strategy to interview village leaders, villagers in relevant government positions, and villagers with a long ancestry in the area.

\section{Results}

\section{Section I. History of the transition to cacao}

In each of the four villages, the majority of farmers I spoke with had made the transition to cacao farming in or around the late 1990s and early 2000s. The majority of land converted to cacao was previously in forest and, prior to that, where land history was known, was primarily used for either wet or dry rice cultivation. This finding is consistent with data collected in the context of the AgFor project, which suggests villagers consistently perceived an increase in cacao production between the 1990s and 2000s and a corresponding decrease in forest cover (Janudianto et al 2012). It is also consistent with initial land-cover change analyses for mainland Southeast Sulawesi over the time period 1990-2001, the time at which cacao would have initially been introduced (Figure 1). 


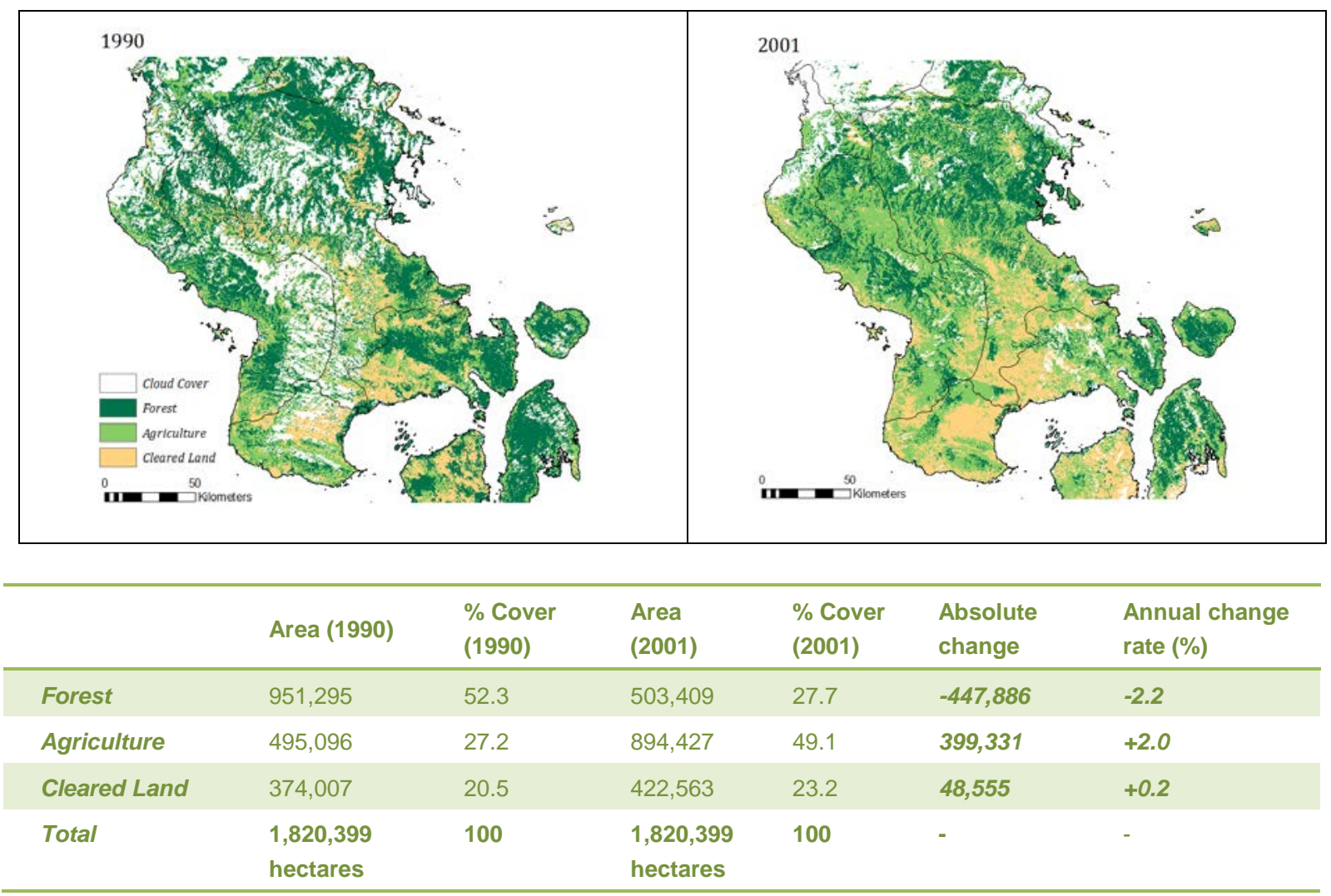

Figure 1. Changes by land-cover classification (mainland Southeast Sulawesi 1990-2001)

Note: Change mapping was conducted using LANDSAT composite imagery; a two-step unsupervised classification process in Erdas Imagine 2011; and spatial analysis in ArcView using the Patch Analyst extension. Data sources and methods are further elaborated in Appendix 1.

In Lawonua and Asipako villages, many villagers associated the rapid transition to cacao with the Sulawesi Rain-Fed Agricultural Development Program (SRFADP). SRFADP was a program funded by the Asian Development Bank, which operated in Sulawesi in the late 1990s with a budget of USD 43.8 million for the goal of encouraging upland development and conservation by supporting rain-fed agriculture. The project was initiated in 1995 but on-the-ground implementation only began in 1999. Through the project, spearheaded within Indonesia by the Directorate General of Estate Crops, roughly 31000 ha of estate crops and 18000 ha of food and horticultural crops were introduced.

The estate crops developed under the project were coconut, coffee, cacao and pepper, listed in order of total area planted (ADB 2003 p.1-3). SRFADP was found to operate somewhat differently in Lawonua and Asipako but, in both, officials from the Directorate General of Estate Crops provided farmers with seeds and compensation that helped to support the initial 'cacao boom' in these villages. This program also helps to explain a decline in forest cover over the period because while the program ostensibly supported upland conservation, farmers were also paid IDR 350000 ( \pm USD 30 in 2014 terms) per hectare to clear the land of all existing vegetation, including secondary forest.

In Lawonua and Wonua Hoa villages, many villagers (including the Bugis) also linked the transition to cacao to the arrival of Bugis migrants in the late 1990s. Bugis farmers I spoke with mentioned they left South Sulawesi because of land scarcity, often following family or neighbours to Southeast 
Sulawesi upon hearing that fertile land was cheaply available. Both Tolaki and Bugis villagers in Lawonua and Wonua Hoa mentioned that while the Bugis were not the first to grow cacao, they were the first to grow monocultural cacao and on areas of land greater than one hectare. The Bugis often brought seeds with them from South Sulawesi.

Finally, many farmers described a process in which cacao farming quickly spread within a given area after farming practices were introduced and both knowledge and seedlings became relatively more available. Bugis migrants were one source of information and seeds, as were farmers in Kolaka Utara, the district immediately west of Konaweha. Many villagers noted that they were motivated to adopt cacao farming after seeing the financial success it brought that area. Seeds were often obtained from relatives in Kolaka Utara, especially among farmers in Ambondia’a and Asipako.

\section{Section II. Current management practices}

There was variation between villages in the structural complexity of farms but farming practices within a given village were generally consistent (Figure 2). In addition to cacao, pepper and sago were commonly cultivated. To varying degrees depending on the village, large- and small-scale corn farms, short-term vegetables (peanuts, spinach, eggplant, cassava), teak and white teak, patchouli, lemongrass and various trees used for fruits and seeds were observed (the latter included banana, coconut, coffee, mango, langsat, rambutan, papaya, durian, cashew, candlenut, betel nut and kapok trees) (Appendix 2). In Lawonua, more than 300 ha had recently been converted from teak and secondary forest to oil palm (this is part of more than 1000 ha in six villages that will be planted with oil palm). There are also several smallholder oil-palm farms in Wonua Hoa, with at least two other villagers raising oil-palm seedlings. This information is consistent with evidence that oil palm is an emerging crop in the region. To date, however, most oil-palm production has been concentrated in the neighbouring district of Kolaka (Janudianto et al 2012).

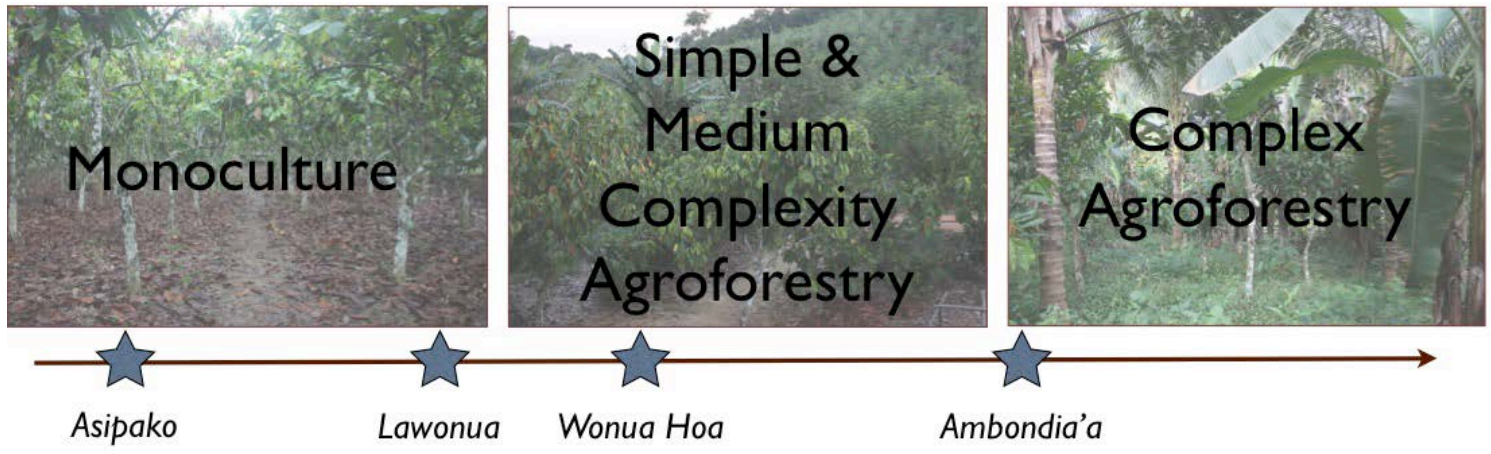

Figure 2. Production classifications in the study villages

In Asipako, cacao farms were structurally the simplest and were almost exclusively under monoculture. In Lawonua, while most farms were under cacao monoculture, a few shade trees were occasionally present. These included coconut, sugar palm, durian and langsat. More commonly, some gamal trees were incorporated into the farm to support peppercorn cultivation. In Wonua Hoa, the largest farms are managed by Bugis, who typically begin growing cacao by intercropping it with 
banana and occasionally plant other fruit trees such as langsat, durian and coconut. In Ambondia'a, farms were relatively complex, characterized by older durian, sago and coconut trees intercropped with cacao. Throughout all four villages, the most structurally diverse cacao farms visited were in home gardens. This land generally was not the farmer's primary land for cacao cultivation and included many trees used for home consumption.

Despite having adopted different growing strategies, villagers suffered from relatively consistent sources of production loss. The most commonly cited problems varied somewhat by village, but included fungal rot, PBK, wildlife pests (particularly monkeys and pigs) and fruit losses associated with heavy rains. Some farmers estimated that as much as $60 \%$ of their crop was affected; several said that cacao farming was no longer profitable; and many mentioned they were actively looking to move away from cacao.

To boost yields and reduce pressure from pests and pathogens, most farmers interviewed were using chemical inputs, including fertilizers, herbicides, pesticides and fungicides. These inputs were not necessarily all used in concert or even used at recommended dosages owing to economic limitations and other access barriers (for example, access to water to mix with pesticides). Facing economic limitations, most farmers said that pesticides were the most important input. Reflecting this, farmers in Asipako and Ambondia'a guarantee local cocoa buyers a portion of their harvest in exchange for upfront cash to buy pesticides. Fungicides were occasionally used in an attempt to reduce Black Pod Rot, but most farmers I spoke with about this felt that fungal pathogens were outside their control, controlled only by the volume and timing of rains. Pruning was also an important strategy, and while nearly all farmers pruned trees to some extent, several mentioned they did this deliberate to manage fungal levels, pruning heavily during the rainy season to allow sun to better dry fruits and trunks.

Farmers employed idiosyncratic methods of dealing with crop losses from monkeys (which are reportedly substantial in some areas of Wonua Hoa and in most of Ambondia'a and Asipako) and pigs, which are a source of crop losses in all four villages. To deal with monkeys, farmers primarily attempt to scare them, using air guns, scarecrows and remaining physically present and loud when monkeys visit their farm. In Asipako, where farms are often not adjacent to farmers' homes, many farmers stayed in temporary shelters on their land during peak harvest times so that they were present to scare the monkeys away. Some farmers in Ambondia'a also mentioned that they lace bananas with poison purchased from agricultural stores in Unahaa, but that this ran the risk of poisoning neighbours' livestock. To deal with pigs, farmers built a variety of traps and fences. Many farmers also mentioned that Balinese migrants from neighbouring villages came to hunt pigs and that this relaxed crop losses.

\section{Section III. Factors influencing the adoption of shade trees}

Farmers expressed or implied various reasons for adopting relatively more complex or relatively more monocultural production strategies. Some of these reasons, discussed below, appear to have a relatively straightforward effect on the inclusion or exclusion of shade trees from farms (Table 1). Other factors had a considerably more variable effect. 
Table 1. Factors influencing the retention or elimination of shade trees

\begin{tabular}{|c|c|c|}
\hline & + & - \\
\hline Sale and consumption & $\begin{array}{l}\text { Sale and consumption of fruits } \\
\text { and seeds }\end{array}$ & Sale and consumption of timber \\
\hline \multirow[t]{2}{*}{$\begin{array}{l}\text { Customary and family- } \\
\text { use arrangements }\end{array}$} & $\begin{array}{l}\text { Separate ownership } \\
\text { arrangements for trees vs. land } \\
\text { (for example, durian, sago) }\end{array}$ & \\
\hline & $\begin{array}{l}\text { Multiple use-rights to certain } \\
\text { trees (for example, durian, sago) }\end{array}$ & \\
\hline $\begin{array}{l}\text { Past generations' } \\
\text { legacy }\end{array}$ & $\begin{array}{l}\text { Desire to preserve trees planted } \\
\text { by parents or grandparents }\end{array}$ & \\
\hline \multirow[t]{2}{*}{ Agricultural extension } & & $\begin{array}{l}\text { SRFADP program in the late 1990s paid } \\
\text { farmers to clear land and instructed them to } \\
\text { remove planted shade trees after four years }\end{array}$ \\
\hline & & $\begin{array}{l}\text { GERNAS program since } 2008 \text { has } \\
\text { distributed grafts, encouraging shade } \\
\text { elimination to enhance graft survival }\end{array}$ \\
\hline $\begin{array}{l}\text { Perceptions of } \\
\text { ecological function }\end{array}$ & & $\begin{array}{l}\text { Perceptions that shade trees lower yields; } \\
\text { facilitate fungal pathogens, waterlogged } \\
\text { fruits and bark moss; attract wildlife; and } \\
\text { create water stress for cacao trees }\end{array}$ \\
\hline
\end{tabular}

\section{Sale and consumption}

Shade trees provide materials for sale and consumption and can be used to establish farm boundaries. Farmers commonly said something like, 'I keep the trees that give me income'. For consumption and sale, langsat, rambutan, durian, coconut, mango, nangka (jack fruit), banana, betel nut, papaya, sago, cashew, candlenut and kapok were observed growing on farms. Various trees were used to establish farm borders, including teak and white teak and kapok. Sale and consumption of timber, however, also motivated the elimination of shade trees, as when a market for coconut wood emerged and many old coconut trees were cleared from farms in Ambondia'a and Asipako.

\section{Customary and family-use arrangements}

In each of the villages visited, trees were not necessarily sold with the land. This was particularly true for durian and sago trees. As a result, trees might be maintained on a farm by an owner because that owner does not have the right to remove the tree. Additionally, while farmers said that trees were only owned by one family member, all family members claimed use rights. This may provide some motivation to keep trees.

\section{Past generations' legacy}

Villagers were evacuated from what are now Ambondia'a and Asipako villages during the period of Darul Islam, beginning in 1955. Villagers began returning to the area to cultivate land as early as the 1960s but the large majority of villagers only returned around 1995 when village-level government was established. Older villagers spoken with in Ambondia'a expressed a desire to preserve trees planted by previous generations, for example, 'I am so proud to come back here and just want to preserve what my parents and grandparents had before’. Villagers also often noted that the current 
generation does not plant such trees and that if they are cut down these trees will not exist in the landscape anymore. A similar motivation may be at work in Wonua Hoa, where many villagers mentioned that durian, coconut and sago trees on their land had been planted by their parents or grandparents.

\section{Agricultural extension: SRFADP and GERNAS}

The role of agricultural extension was pronounced but highly variable across the four study sites. One source of variability was the operations of the above-mentioned SRFADP program in the late 1990s. Importantly, SRFADP operated in Asipako when Ambondia'a was then part of the village not a separate entity as it is now. In or around 1995, Asipako's then village head negotiated with the owners of roughly 150 ha to redistribute it to villagers in equal parcels. This land (and not adjacent land in what is now Ambondia'a) was subsequently marked for participation in the SRFADP program. Through the program, farmers received IDR 350000 per ha to clear the land of all existing vegetation, IDR 300000 per ha for planting cacao and IDR 1500 for each tree planted. Farmers were instructed to plant one shade tree for every four cacao trees and to eliminate shade trees when the cacao trees began to bear fruit. This initial guidance had a clear impact on production strategies (Figure 3). For example, while Asipako is characterized by a full-sun monocultural strategy, multi-storey agroforests predominate in the adjacent village of Ambondia'a. A monocultural production strategy similarly prevails in another of the four study villages where SRFADP was operational: Lawonua.

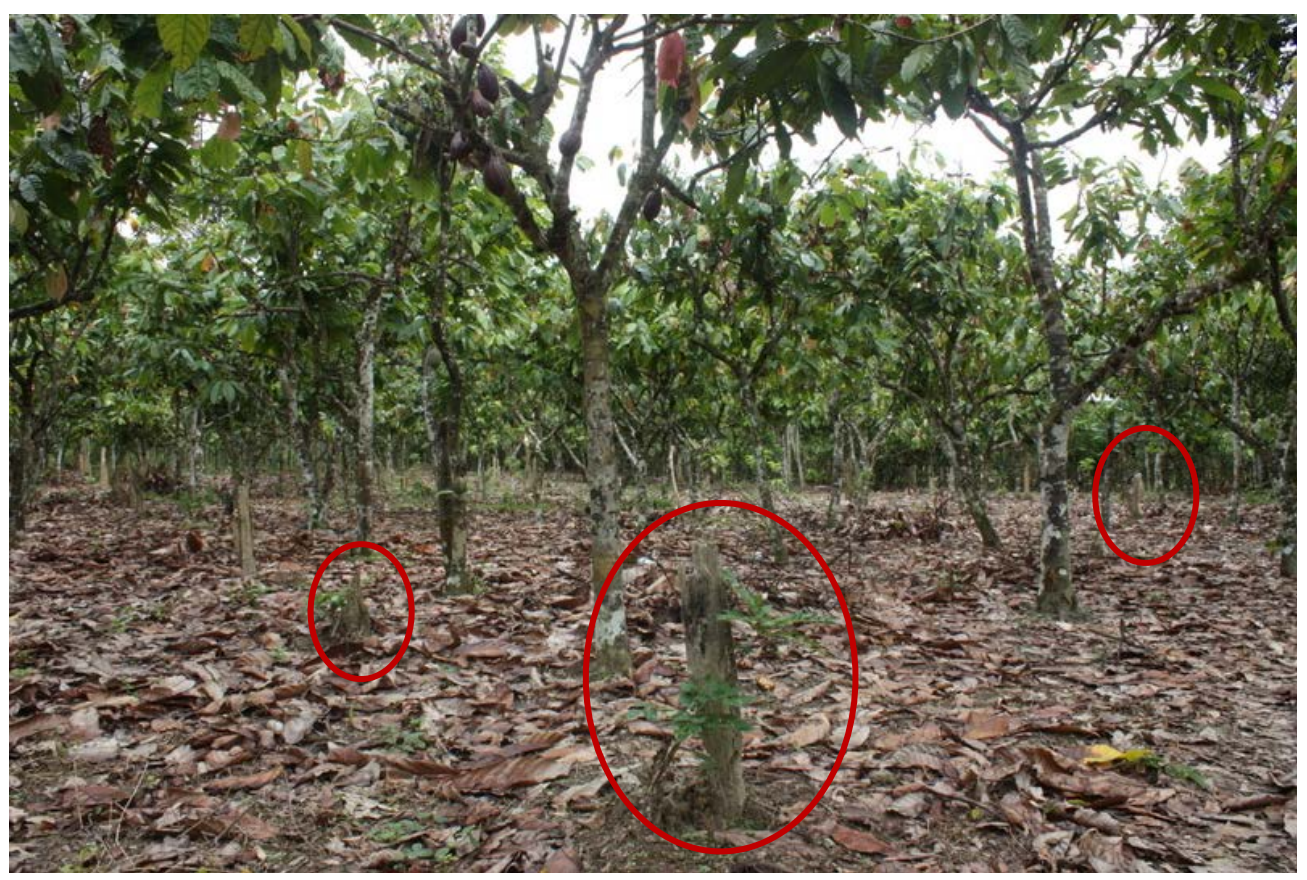

Figure 3. Typical farm in Asipako with cacao monoculture showing evidence of eliminated gamal shade trees

In mid-2008, the Government of Indonesia announced its intention to pursue an increase in cacao production, targeting roughly 300000 ha of already converted land for on-farm intensification (Direktorat Jenderal Perkebunan 2012). This national-level program, Gerakan Peningkatan Produksian Mutu Kakao Nasional (GERNAS/National Movement to Increase the Production and Quality of Cacao) involves the distribution of fertilizers and pesticides on farms younger than 10 years and the distribution of more disease-resistant grafts on farms older than 10 years, as assessed by 
officials from the Directorate General of Estate Crops. This program has been active in two of the four study villages — Lawonua and Ambondia'a — with activities scheduled to begin in Asipako by September 2012. In some cases, farmers were pruning shade and cacao trees heavily to provide newly established grafts with sufficient sunlight to survive. However, given anecdotal accounts that the graft survival rate is low and grafts may not actually be disease resistant, some farmers are leaving old fruit-bearing cacao branches in place to guarantee at least some income.

\section{Perceptions of ecological function}

Farmers commonly expressed that shade trees were bad for cacao production because they reduced yields. One farmer, when asked about how a sugar palm affected cacao, said that, 'It's bad for the cacao, but not as bad as a coconut tree', demonstrating with his arms how coconut tree branches grow horizontally and block sunlight from the cacao. Farmers also mentioned that shade trees reduced the effect of the sun in reducing water on fruit and trees after rain, resulting in more Black Pod Rot, more bark moss (which blocks the formation of new fruits) and more waterlogged young fruit. Shade trees also attracted more monkeys, a key source of production losses in areas with substantial remaining forests.

\section{Labour scarcity and migrants' production practices}

While not seeming to play a strong role in shaping the adoption or retention of shade trees, labour scarcity and migrants' production practices influenced management practices and are worth mentioning.

Particularly in Ambondia'a and Asipako, some older farmers mentioned that they were cultivating cacao as a 'pension'. These farmers often mentioned they lacked the labour power to sufficiently tend their farm, occasionally relying on children or hired help to make up the labour shortage. This situation could have varied impacts on farming practices. Managing pest pressure is time consuming, but managing wildlife and pruning were generally considered both more time consuming and more ineffective (these problems were those most commonly associated with shade trees).

Finally, the Bugis migrants brought with them various production practices, such as intercropping cacao with banana. It is unclear exactly what effect this has had on local land use though it seems reasonable to presume that the Bugis typically grow cacao in a more intensive manner than was common in the area prior to their arrival. This was suggested by local accounts indicating that while the Bugis were not the first to grow cacao, they were the first to grow cacao in monoculture and on areas of land greater than one hectare.

\section{Section IV. Cacao in relation to continuing land developments}

As discussed, in both Lawonua and Wonua Hoa, the transition to cacao has been driven by, and associated with, the arrival of a substantial number of Bugis migrants. In, Wonua Hoa, a substantial portion of land is also under some form of protection ('limited production forest', 'production forest' or 'protected forest').

One observation worth further investigation is that landholdings appear to have been consolidated over the past 10-15 years, with local transactions resulting in apparently high disparities between Bugis and Tolaki farmers. In keeping with this, Bugis farmers commonly reported managing $2-4$ ha 
of land - in both villages - while Tolaki farmers reported an average of 1 ha. It is important to look at fallow landholdings to understand the disparity between this finding and that of Janudianto et al 2012. Yet this finding would be consistent with what has been observed by Li (2002) in Central Sulawesi and will likely interact with emergent oil-palm production in the region to create new incentives and oppositions, as suggested by a farmer in Lawonua.

Mostly, the people that are happy about the oil-palm plantation are the people that don't have land anymore or only have a little land. For people with a lot of land, the plantation doesn't change anything.

Further, and potentially as a result of the many land transactions and restrictions on the further conversion of forested land, the value of land appears to have increased. It is unclear what effect this has had in the study villages though Belcher et al (2005) and others posit that an increase in land values often drives land-use intensification. In addition to contributing to potential land scarcity in Wonua Hoa, land under varying levels of protection has also created a situation of tenure insecurity in Wonua Hoa, Asipako and Ambondia'a. It is unclear what effect this has on farm practices. Ruf (2011) argues that insecure tenure has variable impacts depending on context; that better tenure security can increase incentives to intensify production but that intensification may also be undertaken to establish and protect land rights.

\section{Discussion}

The four study villages were characterized by diverse production strategies. While many villagers in the four study regions have adopted a full-sun, high-density farming strategy, this was not exclusively the case and diverse farming practices persisted. Cacao farmers have experienced widespread production losses across Sulawesi in recent years and losses in Southeast Sulawesi conform to these broader trends. Many farms visited within the four study villages were suffering from pest and pathogen outbreaks as well as production losses associated with wildlife and heavy rains. Farmers were almost ubiquitously reliant on heavy dosages of pesticides and fungicides regardless of their specific farming strategy. Notably, it was on the most structurally diverse farms that farmers were using poison to reduce losses from monkeys. This finding reiterates the importance of examining not just the presence of shade trees on a farm but the range of management practices, suggesting that there is far from the neat correspondence between diversified production strategies and biodiversity protection that is sometimes suggested (for example, Clough et al 2009).

Current levels of production loss also highlight the potential transience of cacao as a livelihood strategy and source of wildlife habitat in Indonesia. This is true not only because of current production losses but also because of emerging livelihood possibilities in the region. One notable development is the expansion of oil palm in Sulawesi, which is already shaping farming decisions in Lawonua. The long-term viability of cacao as a livelihoods' strategy will also be shaped by historical patterns of land transfer in relation to cacao. Land sales to incoming Bugis migrants may have generated both land scarcity as well as landlessness among Tolaki residents. Landlessness may lead some village members to seek waged labour, intensifying incentives for oil palm or other estate crops. 
Finally, this study suggests that diverse non-economic factors shape farmers' management decisions. Looking simply at the role of shade trees, it is apparent that decisions to incorporate shade trees are characterized not only by the effect that shade trees have on yield but also by their value in terms of home consumption, ownership arrangements, and past generations' legacy. One interesting finding is that almost regardless of production strategy, farmers associated shade trees with greater ecological disservice than service. This contradicts many propositions within the ecological literature (see, for example, Tscharntke 2011). A second related finding is that farmers do not associate the structural or compositional diversity of farms with levels of pest pressure, though there is anecdotal and scientific data suggesting pest pressure may be lower on relatively more complex farms. This finding may suggest the relevance of looking at landscape complexity, particularly to understand the incidence of Cacao Pod Borer, a widespread pest in each of the four villages. Because the landscapes in which any one farm exists are now increasingly homogeneous, any one farmer's production decisions likely have a much more limited impact on overall pest and pathogen pressure than does landscape complexity (as per Tscharntke et al 2005). This finding also demonstrates the relevance of examining production contexts. In this area, many losses were due to rain and wildlife. In concordance with farmers' insights, this makes it likely that shade trees do contribute to production losses. It is possible to draw the broad implication from both findings that scientific understanding of the ecological services and disservices of shade trees are of little value isolated from farmers' perceptions and preferences.

In short, far from simply thinking about the economic incentives needed to support relatively more complex agroforestry systems over the short term, this study highlights the need to think about structural factors that may help to support farmers over a relatively longer time frame. Financial support is certainly needed for farmers struggling to earn sufficient livelihoods from cacao farming. Yet this study also makes clear the significant role that institutional support can play in cacao-farming communities. This is apparent not only from the significant way in which SRFADP shaped management practices but also from the sentiment frequently expressed by farmers that they did not know how to cope with production losses and needed guidance on how to rehabilitate their land if they were to continue farming cacao. While ideally the GERNAS program operational between 20082012 would have provided this support, it is clear that in many cases farmers have both mistrusted the inputs and the limited technical advice that went with them. This finding is substantiated by other work done in the context of the AgFor project and in the context of smallholder tree-based systems (for example, Martini et al 2012, Roshetko et al 2008) and suggests the importance of holistic strategies to support smallholders.

\section{Future research directions}

Indonesia's cacao production landscapes are in transition. Public-private partnerships, which have increased globally from one in 1984 to 55 in 2012 (Bitzer et al 2012), seem essential to understanding these transitions. To gain initial understanding of how these partnerships aim to reconfigure cacao production in Indonesia, interviews have been conducted with officials associated with Mars Symbioscience Indonesia, Indonesia Coffee and Cacao Research Institute, Universitas Hasanuddin, World Cocoa Foundation, Cacao Sustainability Partnership and the University of Reading, UK. Findings thus far suggest that Indonesia has come to be considered an important testing ground for new cacao production technologies, including new breeding and propagation techniques. Much of this 
work goes under the banner of corporate-led sustainability, though some of it, including GERNAS, appears more in the form of state-led agricultural extension.

Proposed dissertation research will trace how and why such partnerships have emerged and what are the implications for cacao producers and production landscapes in Indonesia. A case study approach is proposed to compare and contrast different approaches to boosting cacao production, including GERNAS. Field research is planned from June 2014 through June 2015, based in Southeast or South Sulawesi. 


\section{Appendix}

Appendix 1: Land-change data acquisition, resolution and projections

\begin{tabular}{|c|c|c|c|c|}
\hline Data & Source & $\begin{array}{l}\text { Scalel } \\
\text { Resolution }\end{array}$ & $\begin{array}{l}\text { Native } \\
\text { Projection }\end{array}$ & $\begin{array}{l}\text { Analysis } \\
\text { Projection }\end{array}$ \\
\hline $\begin{array}{l}\text { Path: 112, Row: } \\
63(1990,2001)\end{array}$ & Global Land Cover Facility & $30 \mathrm{~m}$ & D_WGS_1984 & D_WGS_1984 \\
\hline $\begin{array}{l}\text { Path: 113, Row: } \\
62(1990,2001)\end{array}$ & $\begin{array}{l}\text { Global Land Cover Facility \& } \\
\text { USGS Earth Explorer }\end{array}$ & $30 \mathrm{~m}$ & D_WGS_1984 & D_WGS_1984 \\
\hline $\begin{array}{l}\text { Path: 113, Row: } \\
63(1991,2001)\end{array}$ & $\begin{array}{l}\text { Global Land Cover Facility \& } \\
\text { USGS Earth Explorer }\end{array}$ & $30 m$ & D_WGS_1984 & D_WGS_1984 \\
\hline $\begin{array}{l}\text { Forest } \\
\text { Clearance } \\
\text { (2004-2012) }\end{array}$ & $\begin{array}{l}\text { Dan Hammer, PhD Student } \\
\text { in Resource Economics }\end{array}$ & $\begin{array}{l}500 m \\
\text { (based on } \\
\text { MODIS } \\
\text { data) }\end{array}$ & D_WGS_1984 & D_WGS_1984 \\
\hline $\begin{array}{l}\text { Administrative } \\
\text { Boundaries }\end{array}$ & http://www.gadm.org/country & & D_WGS_1984 & D_WGS_1984 \\
\hline
\end{tabular}

Note: Individual LANDSAT images were first prepared in ArcView by compositing individual spectral bands 1-5 and 7. Images were subsequently classified in Erdas Imagine 2011. After performing an unsupervised classification (20 classes and 12 iterations), 20 classes were re-coded into 5 classes (forest, agriculture, cleared land, water, and cloud cover). Using a 5,4,1 multispectral band combination, and toggling between satellite and classified images, classes were defined as follows: forest as areas of darkest red; agriculture as areas of lighter red; cleared land as areas of bare earth; water as ocean or lake; and cloud cover as areas for which heavy cloud cover rendered land cover classification impossible. All classified images were then smoothed using a smoothing neighbourhood of 7x7 pixels. After classification, the three relevant LANDSAT images for each time period were merged and clipped to create a land cover map for all of mainland Sulawesi Tenggara for the time periods 1990 and 2001. A series of raster calculations was performed to extract any areas masked by cloud cover in either 1990 or 2001. These calculations first determined all land for which there was data in both the 1990 and 2001 time periods; merged these two rasters and selected from this merged raster only those sites for which data was available in both 1990 and 2001. I then multiplied a binary raster $(1=$ data available, $0=$ no data available) by the original rasters depicting land cover in 1990 and 2001. Rasters were then converted to shapefiles and landscape pattern analysis was performed using the Patch Analyst extension in ArcView. 
Appendix 2: Primary crops cultivated in villages

\begin{tabular}{|c|c|}
\hline Common name & Scientific name \\
\hline Cacao & Theobroma cacao \\
\hline Pepper & Piper nigrum \\
\hline Sago & Metroxylon sagu \\
\hline Peanuts & Arachis hypogaea \\
\hline Spinach & Spinacia oleracea \\
\hline Eggplant & Solanum melongena \\
\hline Cassava & Manihot esculenta \\
\hline Teak & Tectona grandis \\
\hline White Teak & Gmelina arborea \\
\hline Patchouli (nilam) & Pogostemon cablin \\
\hline Lemongrass & Cymbopogon sp. \\
\hline Banana & Musa sp. \\
\hline Coconut & Cocos nucifera \\
\hline Coffee & Coffeaarabica, Coffea robusta \\
\hline Mango & Mangifera indica \\
\hline Langsat & Lansium domesticum \\
\hline Rambutan & Nephelium lappaceum \\
\hline Papaya & Carica papaya \\
\hline Durian & Durio zibethinus \\
\hline Cashew & Anacardium occidentale \\
\hline Candlenut & Aleurites moluccana \\
\hline Betel nut (Areca nut) & Areca catechu \\
\hline Kapok & Ceiba pentandra \\
\hline Oil palm & Elaeis guineensis \\
\hline Gamal & Gliricidia sepium \\
\hline Sugar palm & Arenga pinnata \\
\hline Nangka & Artocarpus heterophyllus \\
\hline
\end{tabular}




\section{References}

[ADB] Asian Development Bank. 2004. Project completion report on the Sulawesi Rain-Fed Agriculture Development Project in Indonesia. Manila: Asian Development Bank.

AgroAsia. Indonesia's Sulawesi cocoa beans exports fall 76.7 percent in August 2011. AgroAsia, 12 September 2011. Accessed 27 April 2012.

http://www.agroasianews.com/commodities/cocoa/11/09/12/indonesias-sulawesi-cocoa-beansexports-fall-767-percent-august-2011.

Belsky JM, Siebert SF. 2003. Cultivating cacao: implications of sun-grown cacao on local food security and environmental sustainability. Agriculture and Human Values 20:277-285.

Bitzer V, Glasbergen P, Leroy P. 2012. Partnerships of a feather flock together? An analysis of the emergence of networks of partnerships in the global cocoa sector. Global Networks 12(3):355-374.

Bos MM, Steffan-Dewenter I, Tscharntke T. 2007. Shade tree management affects fruit abortion, insect pests and pathogens of cocoa. Agriculture, Ecosystems and Environment 120:201-205.

Clarence-Smith WG, ed. 1996. Cocoa pioneer fronts since 1800. London: Macmillan Press.

Clough Y, Faust H, Tscharntke T. 2009. Cacao boom and bust: sustainability of agroforests and opportunities for biodiversity conservation. Conservation Letters 2:197-205.

Direktorat Jenderal Perkebunan. 2012. Pedoman teknis daerah Gerakan Nasional Peningkatan Produksi Dan Mutu Kakao Tahun 2012. Regional technical guidelines of the National Movement for Increased Cocoa Production and Quality 2012. Jakarta: Direktorat Jenderal Perkebunan.

Holt-Giménez E. 2002. Measuring farmers’ agroecological resistance after Hurricane Mitch in Nicaragua: a case study in participatory, sustainable land management impact monitoring. Agriculture, Ecosystems and Environment 93:87-105.

Janudianto, Khususiyah N, Isnurdiansyah, Suyanto, Roshetko JM. 2012. Agroforestry and Forestry in Sulawesi series: livelihood strategies and land-use system dynamics in Southeast Sulawesi. ICRAF Working paper no. 156. Bogor, Indonesia: World Agroforestry Centre (ICRAF) Southeast Asia Regional Program.

Klein A, Steffan-Dewenter I, Tscharntke T. 2002. Predator-prey ratios on cocoa along a land-use gradient in Indonesia. Biodiversity and Conservation 11:683-693.

Leiter J, Harding S. 2004. Trinidad, Brazil and Ghana: three melting moments in the history of cocoa. Journal of rural studies 20:113-130.

Li T. 2002. Local histories, global markets: cocoa and class in Upland Sulawesi. Development and Change 33(3):415-437.

Lin BB, Perfecto I, Vandermeer J. 2008. Synergies between agricultural intensification and climate change could create surprising vulnerabilities for crops. BioScience 58(9):847-854.

Listiyorini E. Cocoa exports from Indonesia's Sulawesi fall on limited supplies. Bloomberg News, 2 April 2012. Accessed 27 April 2012. http://www.businessweek.com/news/2012-04-02/cocoaexports-from-indonesia-s-sulawesi-fall-on-limited-supplies. 
Martini E, Tarigan J, Purnomosidhi P, Prahmono A, Surgana M, Setiawan A, Megawati, Mulyoutami E, Meldy BW, Syamsidar, Talui R, Janudianto, Suyanto, Roshetko JM. 2012. Agroforestry and Forestry in Sulawesi series: agroforestry extension needs at the community level in AgFor project sites in South and Southeast Sulawesi, Indonesia. Working paper no.159. Bogor, Indonesia: World Agroforestry Centre (ICRAF) Southeast Asia Regional Program. DOI: 10.5716/WP12058.

Neilson J. 2007. Global markets, farmers, and the state: sustaining profits in the Indonesian cocoa sector. Bulletin of Indonesian Economic Studies 43(2):227-250.

Pardomuan L. Sulawesi H1 cocoa exports down 41\%. Jakarta Globe,19 July 2011. Accessed 15 April 2012. http://www.thejakartaglobe.com/business/sulawesi-h1-cocoa-exports-down-41/453947.

Roshetko JM, Snelder DJ, Lasco RD, van Noordwijk M. Future challenge: a paradigm shift in the forestry sector. In: Snelder DJ, Lasco RD, eds. Smallholder tree growing for rural development and environmental services. Bonn: Springer Science and Business Media.

Roshetko JM, Suyanto, Dewi S, Sunderland T, Purwanto E, Perdana A, Moeliono M, Umar A, Millang S, Purnomosidhi P, Mahrizal, Martini E, Paramita E, Yuliani L, Finlayson R, Dahlia L. 2013. Agroforestry and forestry in Sulawesi: linking knowledge to action. Annual progress report Year 2 (April 2012-March 2013). Bogor, Indonesia: World Agroforestry Centre (ICRAF) Southeast Asia Regional Program; Center for International Forestry Research; Operation Wallacea Trust; Makassar, Indonesia: Faculty of Forestry, Hasanuddin University; Little Rock, AR: Winrock International.

Ruf F, Siswoputranto PS. 1995. Cocoa cycles: the economics of cocoa supply. Cambridge: Woodhead Publishing.

Ruf F, Schroth G. 2004. Chocolate forests and monocultures: a historical review of cocoa growing and its conflicting role in tropical deforestation and forest conservation. In: Schroth G, da Fonseca GAB, Harvey CA, Gascon C, Vasconcelos HL, Izac AN. Agroforestry and biodiversity conservation in tropical landscapes. Washington, DC: Island Press. p.107-134.

Ruf FO. 2011. The myth of complex cocoa agroforests: the case of Ghana. Human Ecology 39:373388.

Schwendenmann L, Veldkamp E, Moser G, Hölscher D, Köhler M, Clough Y, Anas I, Djajakirana G, Erasmi S, Hertel D, Leitner D, Leuschner C, Michalzik B, Propastin P, Tjoa T, Tscharntke T, van Straaten O. 2010. Effects of an experimental drought on the functioning of a cacao agroforestry system, Sulawesi, Indonesia. Global Change Biology 16:1515-1530.

Steffan-Dewenter I, Kessler M, Barkmann J, Bos MM, Buchori D, Erasmi S, Faust H, Gerold G, Glenk K, Robbert Gradstein S, Guhardja E, Harteveld M, Hertel D, Höhn P, Kappas M, Köhler S, Leuschner C, Maertens M, Marggraf R, Migge-Kleian S, Mogea J, Pitopang R, Schaefer M, Schwarze S, Sporn GS, Steingrebe A, Tjitrosoedirdjo SS, Tjitrosoemito S, Twele A, Weber R, Woltmann L, Zeller M, Tscharntke T. 2007.Trade-offs between income, biodiversity, and ecosystem functioning during tropical rainforest conversion and agroforestry intensification. Proceedings of the National Academy of Sciences 104(12):4973-4978.

Tscharntke T, Klein AM, Kruess A, Steffan-Dewenter I, Thies C. 2005. Landscape perspectives on agricultural intensification and biodiversity: ecosystem service management. Ecological Letters 8:857-874. 
Tscharntke T, Clough Y, Bhagwat SA, Buchori D, Faust H, Hertel D, Hölscher D, Juhrbandt J, Kessler M, Perfecto I, Scherber C, Schroth G, Veldkamp E, Wanger TC. 2011. Multifunctional shade-tree management in tropical agroforestry landscapes: a review. Journal of Applied Ecology 48:619-629.

Vandermeer J, van Noordwidjk M, Anderson J, Ong C, Perfecto I. 1998. Global change and multispecies agroecosystems: concepts and issues .Agriculture, Ecosystems and Environment 67:1-22.

[VECO] VredesEilanden Country Offices. 2011. Increased incomes for Indonesian cocoa farmers in sustainable markets: NGO-private sector cooperation on Sulawesi island. Leuven, Belgium: VredesEilanden Country Offices. http://www.veco-ngo.org/sites/www.vecongo.org/files/blog/bijlage/indonesia-cocoa-case.pdf.

[WCF] World Cacao Foundation. 2007. Indonesia roadmaps for cacao sustainability. Washington, DC: World Cacao Foundation.

World Bank. 2009. Indonesia data and statistics: Export value. Washington, DC: World Bank. 



\section{WORKING PAPERS IN THIS SERIES}

\section{5}

1. Agroforestry in the drylands of eastern Africa: a call to action

2. Biodiversity conservation through agroforestry: managing tree species diversity within a network of community-based, nongovernmental, governmental and research organizations in western Kenya.

3. Invasion of prosopis juliflora and local livelihoods: Case study from the Lake Baringo area of Kenya

4. Leadership for change in farmers organizations: Training report: Ridar Hotel, Kampala, 29th March to 2nd April 2005.

5. Domestication des espèces agroforestières au Sahel : situation actuelle et perspectives

6. Relevé des données de biodiversité ligneuse: Manuel du projet biodiversité des parcs agroforestiers au Sahel

7. Improved land management in the Lake Victoria Basin: TransVic Project's draft report.

8. Livelihood capital, strategies and outcomes in the Taita hills of Kenya

9. Les espèces ligneuses et leurs usages: Les préférences des paysans dans le Cercle de Ségou, au Mali

10. La biodiversité des espèces ligneuses: Diversité arborée et unités de gestion du terroir dans le Cercle de Ségou, au Mali

11. Bird diversity and land use on the slopes of Mt. Kilimanjaro and the adjacent plains, Tanzania

12. Water, women and local social organization in the Western Kenya Highlands

13. Highlights of ongoing research of the World Agroforestry Centre in Indonesia

14. Prospects of adoption of tree-based systems in a rural landscape and its likely impacts on carbon stocks and farmers' welfare: The FALLOW Model Application in Muara Sungkai, Lampung, Sumatra, in a 'Clean Development Mechanism' context

15. Equipping integrated natural resource managers for healthy Agroforestry landscapes.

17. Agro-biodiversity and CGIAR tree and forest science: approaches and examples from Sumatra.

18. Improving land management in eastern and southern Africa: A review of policies.

19. Farm and household economic study of Kecamatan Nanggung, Kabupaten Bogor, Indonesia: A socio-economic base line study of Agroforestry innovations and livelihood enhancement.

20. Lessons from eastern Africa's unsustainable charcoal business.

21. Evolution of RELMA's approaches to land management: Lessons from two decades of research and development in eastern and southern Africa

22. Participatory watershed management: Lessons from RELMA's work with farmers in eastern Africa.

23. Strengthening farmers' organizations: The experience of RELMA and ULAMP.

24. Promoting rainwater harvesting in eastern and southern Africa.

25. The role of livestock in integrated land management.

26. Status of carbon sequestration projects in Africa: Potential benefits and challenges to scaling up.

27. Social and Environmental Trade-Offs in Tree Species Selection: A Methodology for Identifying Niche Incompatibilities in Agroforestry [Appears as AHI Working Paper no. 9]

28. Managing tradeoffs in agroforestry: From conflict to collaboration in natural resource management. [Appears as AHI Working Paper no. 10] 
29. Essai d'analyse de la prise en compte des systemes agroforestiers pa les legislations forestieres au Sahel: Cas du Burkina Faso, du Mali, du Niger et du Senegal.

30. Etat de la recherche agroforestière au Rwanda etude bibliographique, période 1987-2003

2007

31. Science and technological innovations for improving soil fertility and management in Africa: A report for NEPAD's Science and Technology Forum.

32. Compensation and rewards for environmental services.

33. Latin American regional workshop report compensation.

34. Asia regional workshop on compensation ecosystem services.

35. Report of African regional workshop on compensation ecosystem services.

36. Exploring the inter-linkages among and between compensation and rewards for ecosystem services CRES and human well-being

37. Criteria and indicators for environmental service compensation and reward mechanisms: realistic, voluntary, conditional and pro-poor

38. The conditions for effective mechanisms of compensation and rewards for environmental services.

39. Organization and governance for fostering Pro-Poor Compensation for Environmental Services.

40. How important are different types of compensation and reward mechanisms shaping poverty and ecosystem services across Africa, Asia \& Latin America over the Next two decades?

41. Risk mitigation in contract farming: The case of poultry, cotton, woodfuel and cereals in East Africa.

42. The RELMA savings and credit experiences: Sowing the seed of sustainability

43. Yatich J., Policy and institutional context for NRM in Kenya: Challenges and opportunities for Landcare.

44. Nina-Nina Adoung Nasional di So! Field test of rapid land tenure assessment (RATA) in the Batang Toru Watershed, North Sumatera.

45. Is Hutan Tanaman Rakyat a new paradigm in community based tree planting in Indonesia?

46. Socio-Economic aspects of brackish water aquaculture (Tambak) production in Nanggroe Aceh Darrusalam.

47. Farmer livelihoods in the humid forest and moist savannah zones of Cameroon.

48. Domestication, genre et vulnérabilité : Participation des femmes, des Jeunes et des catégories les plus pauvres à la domestication des arbres agroforestiers au Cameroun.

49. Land tenure and management in the districts around Mt Elgon: An assessment presented to the Mt Elgon ecosystem conservation programme.

50. The production and marketing of leaf meal from fodder shrubs in Tanga, Tanzania: A pro-poor enterprise for improving livestock productivity.

51. Buyers Perspective on Environmental Services (ES) and Commoditization as an approach to liberate ES markets in the Philippines.

52. Towards Towards community-driven conservation in southwest China: Reconciling state and local perceptions.

53. Biofuels in China: An Analysis of the Opportunities and Challenges of Jatropha curcas in Southwest China.

54. Jatropha curcas biodiesel production in Kenya: Economics and potential value chain development for smallholder farmers

55. Livelihoods and Forest Resources in Aceh and Nias for a Sustainable Forest Resource Management and Economic Progress 
56. Agroforestry on the interface of Orangutan Conservation and Sustainable Livelihoods in Batang Toru, North Sumatra.

57. Assessing Hydrological Situation of Kapuas Hulu Basin, Kapuas Hulu Regency, West Kalimantan.

58. Assessing the Hydrological Situation of Talau Watershed, Belu Regency, East Nusa Tenggara.

59. Kajian Kondisi Hidrologis DAS Talau, Kabupaten Belu, Nusa Tenggara Timur.

60. Kajian Kondisi Hidrologis DAS Kapuas Hulu, Kabupaten Kapuas Hulu, Kalimantan Barat.

61. Lessons learned from community capacity building activities to support agroforest as sustainable economic alternatives in Batang Toru orang utan habitat conservation program (Martini, Endri et al.)

62. Mainstreaming Climate Change in the Philippines.

63. A Conjoint Analysis of Farmer Preferences for Community Forestry Contracts in the Sumber Jaya Watershed, Indonesia.

64. The highlands: a shared water tower in a changing climate and changing Asia

65. Eco-Certification: Can It Deliver Conservation and Development in the Tropics.

66. Designing ecological and biodiversity sampling strategies. Towards mainstreaming climate change in grassland management.

67. Towards mainstreaming climate change in grassland management policies and practices on the Tibetan Plateau

68. An Assessment of the Potential for Carbon Finance in Rangelands

69 ECA Trade-offs Among Ecosystem Services in the Lake Victoria Basin.

69. The last remnants of mega biodiversity in West Java and Banten: an in-depth exploration of RaTA (Rapid Land Tenure Assessment) in Mount Halimun-Salak National Park Indonesia

70. Le business plan d'une petite entreprise rurale de production et de commercialisation des plants des arbres locaux. Cas de quatre pépinières rurales au Cameroun.

71. Les unités de transformation des produits forestiers non ligneux alimentaires au Cameroun. Diagnostic technique et stratégie de développement Honoré Tabuna et Ingratia Kayitavu.

72. Les exportateurs camerounais de safou (Dacryodes edulis) sur le marché sous régional et international. Profil, fonctionnement et stratégies de développement.

73. Impact of the Southeast Asian Network for Agroforestry Education (SEANAFE) on agroforestry education capacity.

74. Setting landscape conservation targets and promoting them through compatible land use in the Philippines.

75. Review of methods for researching multistrata systems.

76. Study on economical viability of Jatropha curcas L. plantations in Northern Tanzania assessing farmers' prospects via cost-benefit analysis

77. Cooperation in Agroforestry between Ministry of Forestry of Indonesia and International Center for Research in Agroforestry

78. "China's bioenergy future. an analysis through the Lens if Yunnan Province

79. Land tenure and agricultural productivity in Africa: A comparative analysis of the economics literature and recent policy strategies and reforms

80. Boundary organizations, objects and agents: linking knowledge with action in agroforestry watersheds

81. Reducing emissions from deforestation and forest degradation (REDD) in Indonesia: options and challenges for fair and efficient payment distribution mechanisms

82. Mainstreaming climate change into agricultural education: challenges and perspectives 
83. Challenging conventional mindsets and disconnects in conservation: the emerging role of ecoagriculture in Kenya's landscape mosaics

84. Lesson learned RATA garut dan bengkunat: suatu upaya membedah kebijakan pelepasan kawasan hutan dan redistribusi tanah bekas kawasan hutan

85. The emergence of forest land redistribution in Indonesia

86. Commercial opportunities for fruit in Malawi

87. Status of fruit production processing and marketing in Malawi

88. Fraud in tree science

89. Trees on farm: analysis of global extent and geographical patterns of agroforestry

90. The springs of Nyando: water, social organization and livelihoods in Western Kenya

91. Building capacity toward region-wide curriculum and teaching materials development in agroforestry education in Southeast Asia

92. Overview of biomass energy technology in rural Yunnan (Chinese - English abstract)

93. A pro-growth pathway for reducing net GHG emissions in China

94. Analysis of local livelihoods from past to present in the central Kalimantan Ex-Mega Rice Project area

95. Constraints and options to enhancing production of high quality feeds in dairy production in Kenya, Uganda and Rwanda

\section{0}

96. Agroforestry education in the Philippines: status report from the Southeast Asian Network for Agroforestry Education (SEANAFE)

97. Economic viability of Jatropha curcas L. plantations in Northern Tanzania- assessing farmers' prospects via cost-benefit analysis.

98. Hot spot of emission and confusion: land tenure insecurity, contested policies and competing claims in the central Kalimantan Ex-Mega Rice Project area

99. Agroforestry competences and human resources needs in the Philippines

100. CES/COS/CIS paradigms for compensation and rewards to enhance environmental Services

101. Case study approach to region-wide curriculum and teaching materials development in agroforestry education in Southeast Asia

102. Stewardship agreement to reduce emissions from deforestation and degradation (REDD): Lubuk Beringin's Hutan Desa as the first village forest in Indonesia

103. Landscape dynamics over time and space from ecological perspective

104. Komoditisasi atau koinvestasi jasa lingkungan: skema imbal jasa lingkungan program peduli sungai di DAS Way Besai, Lampung, Indonesia

105. Improving smallholders' rubber quality in Lubuk Beringin, Bungo district, Jambi province, Indonesia: an initial analysis of the financial and social benefits

106. Rapid Carbon Stock Appraisal (RACSA) in Kalahan, Nueva Vizcaya, Philippines

107. Tree domestication by ICRAF and partners in the Peruvian Amazon: lessons learned and future prospects in the domain of the Amazon Initiative eco-regional program

108. Memorias del Taller Nacional: "Iniciativas para Reducir la Deforestación en la region Andino Amazónica", 09 de Abril del 2010. Proyecto REALU Peru

109. Percepciones sobre la Equidad y Eficiencia en la cadena de valor de REDD en Perú - Reporte de Talleres en Ucayali, San Martín y Loreto, 2009. Proyecto REALU-Perú.

110. Reducción de emisiones de todos los Usos del Suelo. Reporte del Proyecto REALU Perú Fase 1

111. Programa Alternativas a la Tumba-y-Quema (ASB) en el Perú. Informe Resumen y Síntesis de la Fase II. 2da. versión revisada

112. Estudio de las cadenas de abastecimiento de germoplasma forestal en la amazonía Boliviana 
113. Biodiesel in the Amazon

114. Estudio de mercado de semillas forestales en la amazonía Colombiana

115. Estudio de las cadenas de abastecimiento de germoplasma forestal en Ecuador http://dx.doi.org10.5716/WP10340.PDF

116. How can systems thinking, social capital and social network analysis help programs achieve impact at scale?

117. Energy policies, forests and local communities in the Ucayali Region, Peruvian Amazon

118. NTFPs as a Source of Livelihood Diversification for Local Communities in the Batang Toru Orangutan Conservation Program

119. Studi Biodiversitas: Apakah agroforestry mampu mengkonservasi keanekaragaman hayati di DAS Konto?

120. Estimasi Karbon Tersimpan di Lahan-lahan Pertanian di DAS Konto, Jawa Timur

121. Implementasi Kaji Cepat Hidrologi (RHA) di Hulu DAS Brantas, Jawa Timur. http://dx.doi.org/10.5716/WP10338.PDF

122. Kaji Cepat Hidrologi di Daerah Aliran Sungai Krueng Peusangan, NAD,Sumatra http://dx.doi.org/10.5716/WP10337.PDF

123. A Study of Rapid Hydrological Appraisal in the Krueng Peusangan Watershed, NAD, Sumatra. http://dx.doi.org/10.5716/WP10339.PDF

\section{1}

124. An Assessment of farm timber value chains in Mt Kenya area, Kenya

125. A Comparative financial analysis of current land use systems and implications for the adoption of improved agroforestry in the East Usambaras, Tanzania

126. Agricultural monitoring and evaluation systems

127. Challenges and opportunities for collaborative landscape governance in the East Usambara Mountains, Tanzania

128. Transforming Knowledge to Enhance Integrated Natural Resource Management Research, Development and Advocacy in the Highlands of Eastern Africa. http://dx.doi.org/10.5716/WP11084.PDF

129. Carbon-forestry projects in the Philippines: potential and challenges The Mt Kitanglad Range forest-carbon development. http://dx.doi.org10.5716/WP11054.PDF

130. Carbon forestry projects in the Philippines: potential and challenges. The Arakan Forest Corridor forest-carbon project. http://dx.doi.org10.5716/WP11055.PDF

131. Carbon-forestry projects in the Philippines: potential and challenges. The Laguna Lake Development Authority's forest-carbon development project. http://dx.doi.org/10.5716/WP11056.PDF

132. Carbon-forestry projects in the Philippines: potential and challenges. The Quirino forest-carbon development project in Sierra Madre Biodiversity Corridor. http://dx.doi.org10.5716/WP11057.PDF

133. Carbon-forestry projects in the Philippines: potential and challenges. The Ikalahan Ancestral Domain forest-carbon development. http://dx.doi.org10.5716/WP11058.PDF

134. The Importance of Local Traditional Institutions in the Management of Natural Resources in the Highlands of Eastern Africa. http://dx.doi.org/10.5716/WP11085.PDF

135. Socio-economic assessment of irrigation pilot projects in Rwanda. http://dx.doi.org/10.5716/WP11086.PDF

136. Performance of three rambutan varieties(Nephelium lappaceum L.) on various nursery media. http://dx.doi.org/10.5716/WP11232.PDF 
137. Climate change adaptation and social protection in agroforestry systems: enhancing adaptive capacity and minimizing risk of drought in Zambia and Honduras.

http://dx.doi.org/10.5716/WP11269.PDF

138. Does value chain development contribute to rural poverty reduction? Evidence of asset building by smallholder coffee producers in Nicaragua. http://dx.doi.org/10.5716/WP11271.PDF

139. Potential for biofuel feedstock in Kenya. http://dx.doi.org/10.5716/WP11272.PDF

140. Impact of fertilizer trees on maize production and food security in six districts of Malawi. http://dx.doi.org/10.5716/WP11281.PDF

\section{2}

141. Fortalecimiento de capacidades para la gestión del Santuario Nacional Pampa Hermosa:

Construyendo las bases para un manejo adaptativo para el desarrollo local. Memorias del Proyecto. http://dx.doi.org/10.5716/WP12005.PDF

142. Understanding rural institutional strengthening: A cross-level policy and institutional framework for sustainable development in Kenya. http://dx.doi.org/10.5716/WP12012.PDF

143. Climate change vulnerability of agroforestry. http://dx.doi.org/10.5716/WP16722.PDF

144. Rapid assesment of the inner Niger delta of Mali. http://dx.doi.org/10.5716/WP12021.PDF

145. Designing an incentive program to reduce on-farm deforestationin the East Usambara Mountains, Tanzania. http://dx.doi.org/10.5716/WP12048.PDF

146. Extent of adoption of conservation agriculture and agroforestry in Africa: the case of Tanzania, Kenya, Ghana, and Zambia. http://dx.doi.org/10.5716/WP12049.PDF

147. Policy incentives for scaling up conservation agriculture with trees in Africa: the case of Tanzania, Kenya, Ghana and Zambia. http://dx.doi.org/10.5716/WP12050.PDF

148. Commoditized or co-invested environmental services? Rewards for environmental services scheme: River Care program Way Besai watershed, Lampung, Indonesia. http://dx.doi.org/10.5716/WP12051.PDF

149. Assessment of the headwaters of the Blue Nile in Ethiopia. http://dx.doi.org/10.5716/WP12160.PDF

150. Assessment of the uThukela Watershed, Kwazaulu. http://dx.doi.org/10.5716/WP12161.PDF

151. Assessment of the Oum Zessar Watershed of Tunisia. http://dx.doi.org/10.5716/WP12162.PDF

152. Assessment of the Ruwenzori Mountains in Uganda. http://dx.doi.org/10.5716/WP12163.PDF

153. History of agroforestry research and development in Viet Nam. Analysis of research opportunities and gaps. http://dx.doi.org/10.5716/WP12052.PDF

154. REDD+ in Indonesia: a Historical Perspective. http://dx.doi.org/10.5716/WP12053.PDF

155. Agroforestry and Forestry in Sulawesi series: Livelihood strategies and land use system dynamics in South Sulawesi http://dx.doi.org/10.5716/WP12054.PDF

156. Agroforestry and Forestry in Sulawesi series: Livelihood strategies and land use system dynamics in Southeast Sulawesi. http://dx.doi.org/10.5716/WP12055.PDF

157. Agroforestry and Forestry in Sulawesi series: Profitability and land-use systems in South and Southeast Sulawesi. http://dx.doi.org/10.5716/WP12056.PDF

158. Agroforestry and Forestry in Sulawesi series: Gender, livelihoods and land in South and Southeast Sulawesi http://dx.doi.org/10.5716/WP12057.PDF

159. Agroforestry and Forestry in Sulawesi series: Agroforestry extension needs at the community level in AgFor project sites in South and Southeast Sulawesi, Indonesia. http://dx.doi.org/10.5716/WP12058.PDF

160. Agroforestry and Forestry in Sulawesi series: Rapid market appraisal of agricultural, plantation and forestry commodities in South and Southeast Sulawesi. http://dx.doi.org/10.5716/WP12059.PDF 


\section{3}

161. Diagnosis of farming systems in the Agroforestry for Livelihoods of Smallholder farmers in Northwestern Viet Nam project. http://dx.doi.org/10.5716/WP13033.PDF

162. Ecosystem vulnerability to climate change: a literature review. http://dx.doi.org/10.5716/WP13034.PDF

163. Local capacity for implementing payments for environmental services schemes: lessons from the RUPES project in northeastern Viet Nam. http://dx.doi.org/10.5716/WP13046.PDF

164. Seri Agroforestri dan Kehutanan di Sulawesi: Agroforestry dan Kehutanan di Sulawesi: Strategi mata pencaharian dan dinamika sistem penggunaan lahan di Sulawesi Selatan. http://dx.doi.org/10.5716/WP13040.PDF

165. Seri Agroforestri dan Kehutanan di Sulawesi: Mata pencaharian dan dinamika sistem penggunaan lahan di Sulawesi Tenggara http://dx.doi.org/10.5716/WP13041.PDF

166. Seri Agroforestri dan Kehutanan di Sulawesi: Profitabilitas sistem penggunaan lahan di Sulawesi Selatan dan Sulawesi Tenggara http://dx.doi.org/10.5716/WP13042.PDF

167. Seri Agroforestri dan Kehutanan di Sulawesi: Gender, mata pencarian dan lahan di Sulawesi Selatan dan Sulawesi Tenggara http://dx.doi.org/10.5716/WP13043.PDF

168. Seri Agroforestri dan Kehutanan di Sulawesi: Kebutuhan penyuluhan agroforestri pada tingkat masyarakat di lokasi proyek AgFor di Sulawesi Selatan dan Tenggara, Indonesia. http://dx.doi.org/10.5716/WP13044.PDF

169. Seri Agroforestri dan Kehutanan di Sulawesi: Laporan hasil penilaian cepat untuk komoditas pertanian, perkebunan dan kehutanan di Sulawesi Selatan dan Tenggara. http://dx.doi.org/10.5716/WP13045.PDF

170. Agroforestry, food and nutritional security. http://dx.doi.org/10.5716/WP13054.PDF

171. Stakeholder Preferences over Rewards for Ecosystem Services: Implications for a REDD+ Benefit Distribution System in Viet Nam. http://dx.doi.org/10.5716/WP13057.PDF

172. Payments for ecosystem services schemes: project-level insights on benefits for ecosystems and the rural poor. http://dx.doi.org/10.5716/WP13001.PDF

173. Good practices for smallholder teak plantations keys to success. http://dx.doi.org/10.5716/WP13246.PDF

174. Market analysis of selected agroforestry products in the Vision for Change Project intervention Zone, Côte d'Ivoire.

175. Rattan futures in Katingan: why do smallholders abandon or keep their gardens in Indonesia's 'rattan district'? http://dx.doi.org/10.5716/WP13251.PDF

176. Management along a Gradient: Southeast Sulawesi's Cacao Production Landscape http://dx.doi.org/10.5716/WP13246.PDF 


The World Agroforestry Centre is an autonomous, non-profit research organization whose vision is a rural transformation in the developing world as smallholder households increase their use of trees in agricultural landscapes to improve food security, nutrition, income, health, shelter, social cohesion, energy resources and environmental sustainability. The Centre generates science-based knowledge about the diverse roles that trees play in agricultural landscapes, and uses its research to advance policies and practices, and their implementation that benefit the poor and the environment. It aims to ensure that all this is achieved by enhancing the quality of its science work, increasing operational efficiency, building and maintaining strong partnerships, accelerating the use and impact of its research, and promoting greater cohesion, interdependence and alignment within the organization.

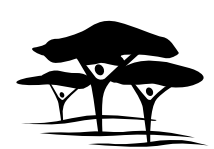

United Nations Avenue, Gigiri • PO Box 30677 • Nairobi, $00100 \cdot$ Kenya Telephone: +254207224000 or via USA +1 6508336645

Fax: +254207224001 or via USA +1 6508336646

Email: worldagroforestry@cgiar.org •www.worldagroforestry.org

Southeast Asia Regional Program • Sindang Barang • Bogor 16680

PO Box $161 \cdot$ Bogor $16001 \cdot$ Indonesia

Telephone: +62 $2518625415 \cdot$ Fax: +62 2518625416

Email: icraf-indonesia@cgiar.org•www.worldagroforestry.org/regions/southeast_asia 